\title{
SISTEM INFORMASI PENGGAJIAN KARYAWAN KSP TALENTA
}

\author{
Agustinus Fritz Wijaya, Aprisal Eliezer \\ Fakultas Teknologi Informasi, Universitas Kristen Satya Wacana \\ Jl. Blotongan, Sidorejo Lor, Sidorejo, Kota Salatiga, Jawa Tengah 50714 \\ e-mail: sagustinus.wijaya@staff.uksw.edu
}

\begin{abstract}
Abstrak
Pada sebuah perusahaan adanya sistem informasi penggajian sangatlah penting, untuk meningkatkan kelancaran sebuah proses pembayaran gaji pada setiap karyawan. Maka dari itu dibutuhkan sebuah sistem informasi penggajian untuk memberikan kemudahan dan kelancaran dalam penggajian karyawan. Selama ini proses penggajian karyawan di koperasi simpan pinjam Talenta belum terkomputerisasi atau masih manual, sehingga setiap pengolahan data yang dilakukan semakin membutuhkan waktu dan beresiko tinggi dalam proses penginputannya, jika terjadi kesalahan akan berakibat fatal. Dengan tidak adanya sistem informasi penggajian, maka penginputan data dan penyusunan laporan diperlukan ketelitian yang tinggi, karena data dapat berubah setiap waktu. Oleh karena itu pada penelitian ini secara keseluruhan telah dihasilkan aplikasi sistem informasi penggajian.
\end{abstract}

Kata kunci: Sistem Informasi, Teknologi Informasi, Penggajian Karyawan, Koperasi Simpan Pinjam

\section{Pendahuluan}

Pada jaman ini semua yang serba otomatis sangat dicari untuk memudahkan dalam sebuah pekerjaan, Sistem informasi yang telah terkomputerisasi sangat membantu dalam mengerjakan sebuah kegiatan jika dibandingkan dengan manual. Penerapan Sistem informasi pada segala bidang merupakan hal yang dicari-cari dikarenakan ini sangat membantu, dalam mengerjakan sebuah masalah ini bisa dikatakan lebih cepat. Sebuah informasi yang dikumpulkan dengan menggunakan Sistem informasi yang telah terkomputerisasi akan sangat berbeda dengan Sistem Informasi yang belum terkomputerisasi. Hasil yang dihasilkan oleh Sistem Informasi yang terkomputerisasi lebih aktual dan akurat jika dibandingkan dengan proses yang belum terkomputerisasi atau yang biasa disebut manual.

KSP Talenta adalah sebuah koperasi simpan pinjam yang beralamat di Jl. Kalipengging No.44, Kutowinangun Kidul, Tingkir, Kota Salatiga, Jawa Tengah, Indonesia atau biasa disebut koperasi kredit, KSP Talenta adalah lembaga keuangan yang berdiri sendiri/non bank dimana akan memberikan solusi dalam hal penambahan modal usaha kepada para nasabah/anggotanya. Untuk menjadi nasabah dari KSP Talenta, calon nasabah harus mendaftarkan diri di dalam KSP Talenta tersebut. Jika belum mendaftarkan diri maka tidak bisa menyimpan maupun meminjam uang dari KSP Talenta tersebut.

KSP Talenta merupakan salah satu dari sekian banyak koperasi di Salatiga yang masih melakukan penggajian karyawan secara manual atau belum terkomputerisasi. Sistem manual seperti ini sangat tidak efektif karena membutuhkan banyak waktu. Sistem yang berjalan saat ini masih mengalami banyak kendala diantaranya dalam proses pembuatan slip karyawan karena belum terkomputerisasi. Selain itu, pada penginputan data dan informasi karyawan sering didapati data dan informasi yang tidak akurat. Pihak bendahara yang berperan dalam proses penggajian juga kesulitan dalam melakukan proses pembuatan laporan gaji karyawan. Kesalahan dalam penghitungan gaji akan berdampak sangat fatal karena sangat berpengaruh dalam pembuatan laporan keuangan. Sistem yang terkomputerisasi sangat dibutuhkan dalam 
hal ini. Penelitian ini menghasilkan sebuah sistem informasi penggajian, yang akan sangat membantu bendahara dalam melakukan rekap dan pengolahan gaji pada KSP Talenta.

Penelitian-penelitian yang menggunakan tema tentang Sistem Informasi Penggajian telah banyak dilakukan sebelumnya dan ini sangat membantu sekali untuk menjadi referensi dalam pembuatan "Sistem Informasi Penggajian Karyawan KSP TALENTA" ini. Contoh penelitianpenelitian yang sebelumnya yaitu:

"Sistem Informasi Penggajian dan Kepegawaian Berbasis Dekstop (Studi Kasus: Sekolah Menengah Atas (SMA) Negeri 2 Waingapu)" Penelitian ini menghasilkan rancangan dan sebuah aplikasi Sistem informasi penggajian berbasis dekstop untuk kemajuan yang dapat mempermudah dalam membuat dokumentasi sistem penggajian pegawai pada sekolah SMA Negeri 2 Waingapu dan memudahkan dalam memproses pengolahan data pegawai maupun gaji untuk menghasilkan informasi bagi User (kepala Sekolah) yang efektif dan efisien.

"Sistem Informasi Penggajian Karyawan Shift Khusus Pagi PT. Tiga Manunggal Synthetic Industries" Pada penelitian kedua ini hasilnya adalah dapat mengetahui dan menganalisis Sistem informasi penggajian karyawan di PT. Tiga Manunggal Synthetic Industries dan Merancang sistem sederhana mengenai perhitungan penggajian dan tampilan laporan yang sesuai dengan label gaji PT. Tiga Manunggal Synthetic Industries.

Penelitian yang ketiga yaitu "Perancangan Sistem Informasi Penggajian Karyawan berbasis Dekstop (Studi Kasus:PT. BS Logistics Batam)" penelitian ini menghasilkan sebuah sistem informasi penggajian dan merancang sistem informasi penggajian berbasis desktop yang efektif dan efisien.

\section{Metode Penelitian}

Jenis penelitian yang dilakukan adalah jenis penelitian kualitatif dimana data yang diperoleh merupakan hasil dari sebuah tanya jawab/wawancara yang didapatkan dari beberapa narasumber yang bekerja pada KSP Talenta. Data yang diperoleh dari hasil wawancara tersebut akan dikumpulkan dan diolah penulis untuk proses pembangunan sistem informasi penggajian, narasumber yang bersedia dalam membagi informasi untuk pembangunan sistem ini ialah dari pihak Karyawan KSP Talenta yang telah memiliki ijin atau wewenang untuk mengolah data-data karyawan yang berhubungan dengan data gaji karyawan. Data-data yang terkumpul adalah data pegawai, Jabatan, Tunjangan dan Potongan serta data proses perhitungan gaji karyawan yang diberikan oleh pihak Manajer KSP Talenta. Untuk proses pengumpulan data pada penelitian ini dilakukan dengan beberapa cara yaitu melakukan observasi dan pengamatan langsung terhadap aktivitas di KSP Talenta tersebut, wawancara terhadap Karyawan KSP Talenta yang telah memiliki ijin atau wewenang untuk mengolah datadata karyawan yang berhubungan dengan data gaji karyawan dan melakukan dokumentasi, yaitu teknik pengumpulan data dengan cara mengambil data dari dokumen atau arsip yang ada. Pengumpulan data ini nantinya akan menghasilkan sebuah informasi untuk membangun sebuah sistem dan juga kondisi sistem saat ini seperti apa sehingga dapat menjadi pedoman untuk pembuatan penelitian ini.

Metode yang digunakan dalam perancangan sistem informasi penggajian pada penelitian ini yaitu model Prototyping. Model Prototyping ini merupakan salah satu dari sekian banyak metode pengembangan perangkat lunak.

Metode ini dipilih oleh penulis karena prototype dibentuk untuk lebih memudahkan dalam proses pembuatan aplikasi. Kegunaan dari Metode prototype untuk memperbaiki sistem yang sudah ada atau yang akan dikembangkan, sehingga pengembang dari perangkat lunak tersebut tidak harus merancang sistem lagi dari nol. 


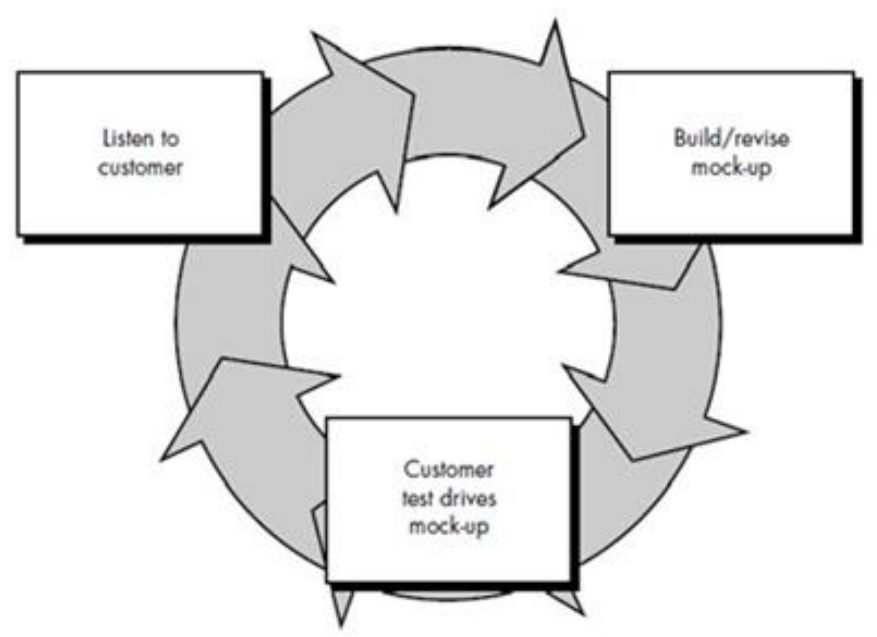

Gambar 1. Bagian Prototype

Penjelasan pada Gambar 1 yang ada pada Bagan Prototype yaitu sebagai berikut:

I. Listen to customer:Tahapan dimana untuk menganalisa kebutuhan apa saja yang akan dibutuhkan dalam sebuah proses perancangan. Di tahapan ini kita dapat mengidentifikasi kebutuhan awal dari sistem, yang diperoleh dari hasil wawancara. Berdasarkan hasil wawancara tersebut dapat diketahui bahwa sistem yang digunakan masih menggunakan metode manual.

II. Build/revise mock-up: Tahapan yang dilakukan proses perancangan sementara, agar bisa menghasilkan suatu perancangan tampilan antar muka (interface) aplikasi dari sistem informasi penggajian. Tahapan ini menyajikan gambaran kepada pembangun maupun klien dalam proses untuk mengembangkan sistem atau aplikasi yang akan dirancang dengan menggunakan sebuah bahasa pemrogaman.

III. Customer test-drives mock-up: Merupakan tahap melakukan tes, di tahapan ini User akan diberikan hasil perancangan oleh pengembang untuk di evalusi. Jika hasil perancangan yang di hasilkan tidak sesuai maka akan diperbaiki lagi oleh pengembang. Ketika telah sepakat maka pengembang akan membuat aplikasi penggajian.

\section{Hasil dan Pembahasan}

Perancangan sistem yaitu merancang atau mendesain yang digunakan dalam membentuk sebuah aplikasi dikarenakan proses ini adalah proses dimana kita menggambarkan suatu sistem yang dibentuk dari mulai awal penggambaran perencanaan sampai pada tahapan akhir yaitu pembuatan fungsi yang digunakan untuk berjalanya sebuah aplikasi. Perancangan sistem sangat dibutuhkan karena digunakan untuk mengetahui apakah sistem yang dibangun sesuai dengan yang diinginkan dan apakah dapat memenuhi kepentingan dari pengguna tersebut. Pada Perancangan sistem informasi penggajian ini diagram yang digunakan yaitu meliputi use case diagram, activity diagram dan class diagram.

\subsection{Use Case Diagram}

Pengertian dari Use Case Diagram yaitu bentuk dari sebuah hubungan yang membantu dalam membangun sebuah sistem antara use case dan aktor tersebut. Di dalam Use Case Diagram digambarkan upaya menjadi sesuatu yang berguna mengenai apa saja yang dibutuhkan pada sistem tersebut. Pada Use case aktor adalah orang atau mesin yang berinteraksi terhadap sistem untuk melakukan sebuah pekerjaan-pekerjaan tertentu. Ada 2 aktor pada Uses Case Diagram yang terdapat di aplikasi ini yaitu administrator (ADMIN) dan User, Bendahara sebagai Admin dan Kepala Pimpinan Sebagai User pada aplikasi ini. Pada penggunaan aplikasi ini peran dari setiap aktor ini berbeda-berbeda. 


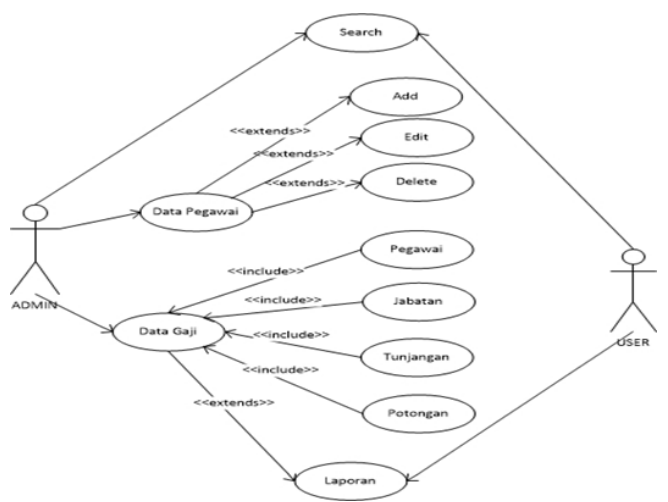

Gambar 2. Uses Case Diagram

Gambar 2 Merupakan tampilan Uses Case Diagram dari Sistem Informasi Penggajian Karyawan KSP TALENTA. Penjelasan dari Gambar 2 ini yaitu: administrator (ADMIN), admin memiliki peran sebagai aktor yang memiliki semua hak seperti menghapus, mengubah dan menambah data pegawai, data gaji maupun mebuat sebuah laporan yang akan diberikan pada User. User, User memiliki peran sebagai aktor yang berhak untuk menerima hasil laporan yang telah dikerjakan, dengan begitu User akan mudah dalam melakukan proses pemantauan maupun pengecekan terhadap perusahaan yang dipimpinnya itu.

\subsection{Activity Diagram}

Activity Diagram adalah gambaran dari alur kerja yang berisikan aktivitas dan sebuah tindakan dari sebuah alur kotrol yang sedang dirancang pada sebuah aplikasi dari komputer. Kegunaan Activity Diagram juga digunakan untuk mendefinisikan dari sebuah urutan atau pengelompokan sebuah User interface atau yang disebut dengan tampilan. Pada setiap aktivitas Activity Diagram dianggap memiliki sebuah interface serta menu yang akan ditampilkan pada perangakat lunak.

Dalam Activity Diagram juga dapat menggambarkan urutan aktivitas dan proses bisnis, agar proses tersebut dapat lebih mudah dipahami. Activity diagram juga digunakan dengan tunjuan menunjukkan aliran pesan pada satu aktivitas ke aktivitas lainnya

Tujuan Lain dari pembuatan Activity Diagram yaitu dapat Membantu dalam memahami sebuah proses dengan menyeluruh, menggambarkan urutan aktivitas dan proses bisnis, agar proses tersebut dapat lebih mudah dipahami dan memudahkan dalam pembentukan gambar aliran paralel, bersamaan dan bercabang dari sebuah sistem.

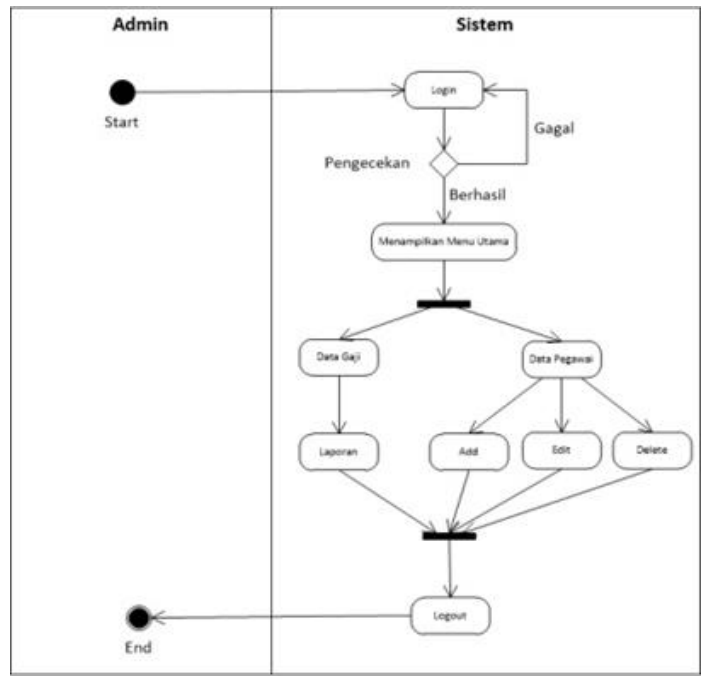

Gambar 3. Activity Diagram Administrator

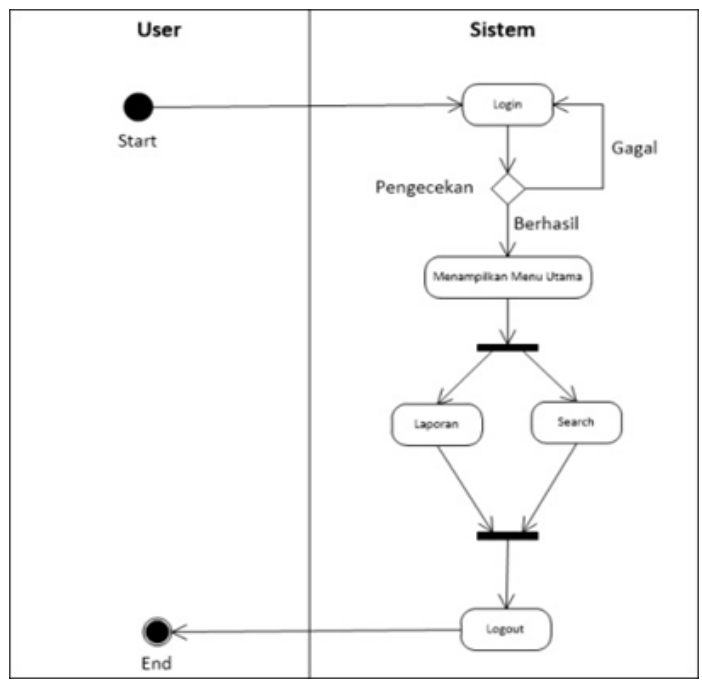

Gambar 4. Activity Diagram User 
Pada Gambar 3 merupakan Activity Diagram Administrator pertama-tama untuk memulai aktivitas dengan cara login terlebih dahulu yang ada didalam bagian sistem, setelah melakukan proses Login maka akan dilakukan pengecekan jika gagal akan kembali ke Login, pengecekan akan dilakukan terus-menerus sampai berhasil, jika berhasil akan masuk ke dalam tampilan halaman menu utama. Kemudian setelah masuk kedalam menu utama, maka sistem akan menampilkan Data Gaji dan Data Pegawai, dalam Data Pegawai seorang Admin bisa mengontrol penuh yaitu menambahkan, mengubah dan menghapus data pada Data pegawai. Jika sudah selesai dengan kebutuhan maka User bias melakukan Logout/keluar dari aplikasi

Gambar 4 merupakan alur dari Activity Diagram User pertama-tama untuk memulai yaitu adalah Log in yang ada didalam bagian sistem, setelah melakukan proses Login maka akan dilakukan pengecekan jika gagal akan kembali ke Login, jika berhasil akan masuk ke dalam tampilan halaman menu utama. User dapat melihat laporan dan mencari data untuk data individu pegawai, serta laporan gaji. Jika sudah selesai dengan kebutuhan maka User bias melakukan Logout/keluar dari aplikasi.

\subsection{Class Diagram}

Class Diagram adalah sebuah diagram yang menggambarkan tentang pengelompokan terhadap bagian-bagian dari sistem yang akan dibuat. Didalam pengelompokan terdapat 3 kelas utama yaitu attribute, operation, dan name dan dari kelas yang satu ke kelas yang lain saling berelasi. 3 kelas-kelas tersebut harus dapat melakukan fungsi-fungsi dalam menyesuaikan kebutuhan sistem. Sebuah struktur kelas yang baik yaitu memiliki susunan jenisjenis kelas berikut : Kelas Main (Merupakan kelas yang memiliki fungsi ketika sebuah sistem mulai untuk dijalankan), Kelas Interface (Kelas yang mengatur dan mendefinisikan interface/tampilan kepada si pemakai. Kelas interface merupakan sebuah kelas yang dapat menangani fungsi-fungsi dari apa yang harus ada dan diambil dari usecase) dan Kelas Entitas (Merupakan kelas yang dibutuhkan untuk memegang atau menangani data untuk menjadi sebuah kelompok).

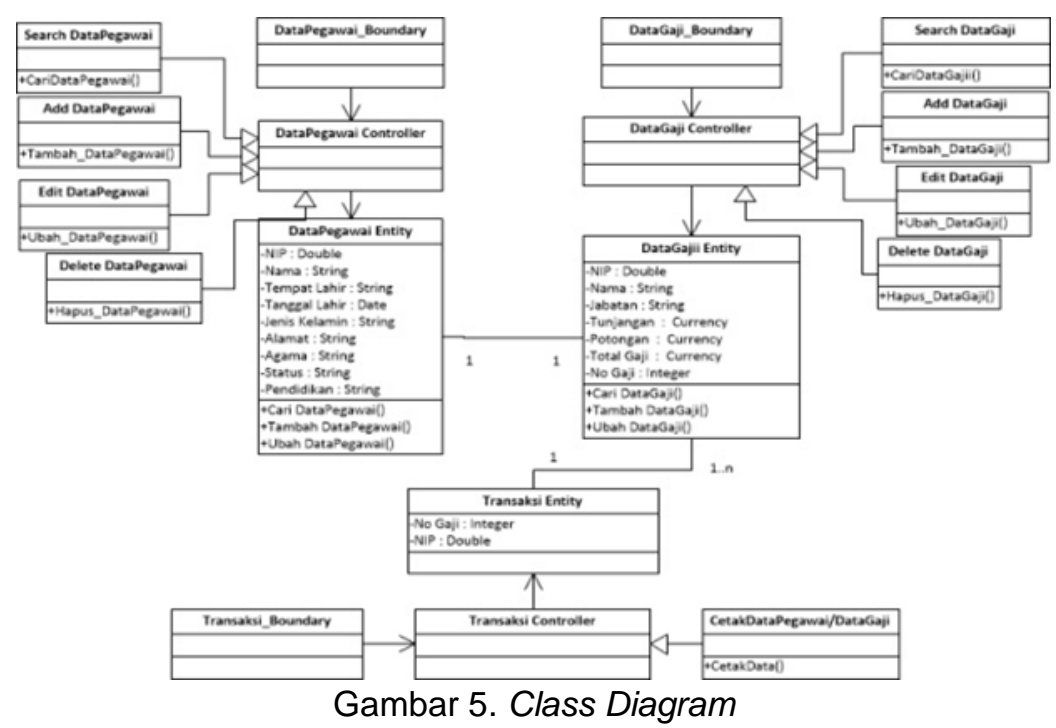

Gambar 5 merupakan Class Diagram yang telah penulis rancang pada sistem informasi kepegawaian dan penggajian pada KSP Talenta. Apabila saat melakukan proses log in sebagai admin, maka akan secara otomatis terhubung dengan class mengelola data dengan beberapa atribute yang ada pada class mengelola yaitu seperti menambah, mengubah, dan menghapus. Jika saat melakukan login sebagai User, maka sistem akan secara otomatis dihubungkan pada class yang hanya bisa di tampilkan di User yaitu class laporan gaji dan pada class search data pegawai. 


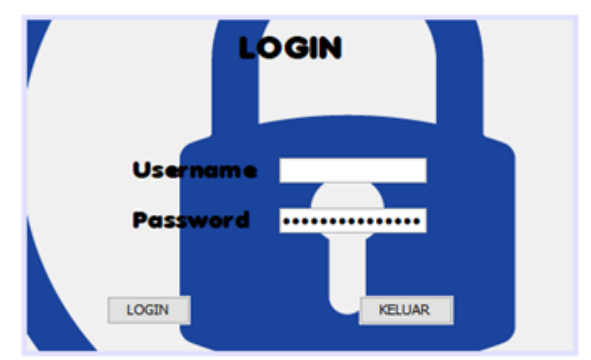

Gambar 6. Halaman Login

Gambar 6 adalah tampilan awal saat proses menjalakan aplikasi. Dalam tampilan ini terdapat dua tombol Login dan tombol Keluar. Fungsi dari tombol Login yaitu untuk masuk ke menu utama dan sedangkan fungsi Keluar yaitu untuk tidak melanjutkan jalanya dari aplikasi/ keluar dari aplikasi tersebut. Ketika melakukan proses Login sistem akan melakukan pengecekan Usemame dan Password apakah sesuai dan sistem akan membedakan antara admin maupun User(Kepala KSP). Jika sesuai maka sistem akan mengarahkan langsung ke Menu Utama. Jika Usemame dan Password yang di inputkan salah maka harus melakukan login ulang.

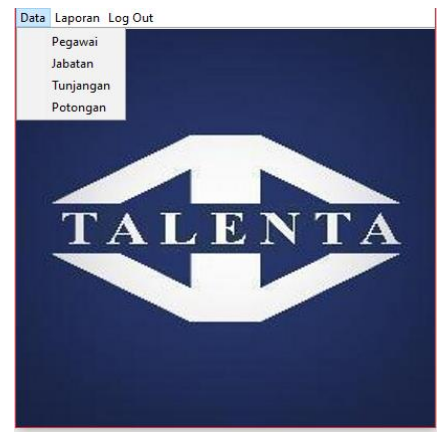

Gambar 7. Menu Utama (Admin)

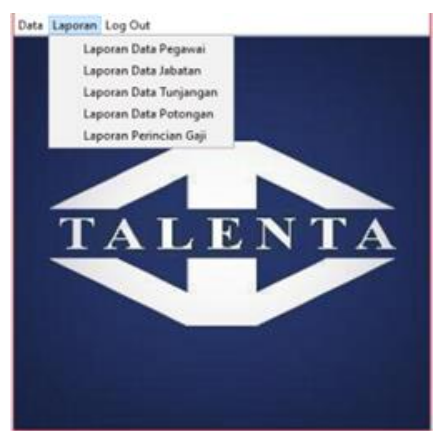

Gambar 8. Menu Utama (Admin)

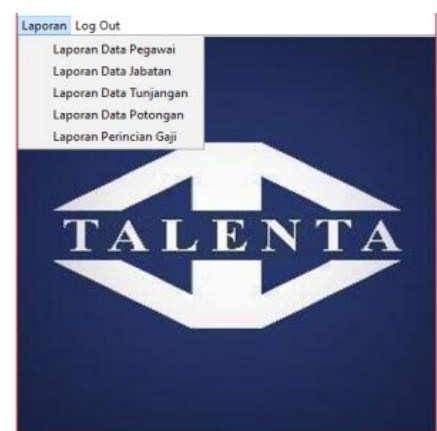

Gambar 9. Menu Utama

(User)

Pada Gambar 7, 8 dan 9 adalah proses dimana ketika setelah melakukan Login maka akan dilanjutkan ke Menu Utama. Gambar 7 dan Gambar 8 adalah tampilan dari menu utama dari Admin yang bisa memegang kontrol penuh pada aplikasi. Pada menu bar Data didalamnya ada Pegawai, Jabatan, Tunjangan dan Potongan. Pada menu bar Laporan didalamnya berisikan Laporan Data Pegawai, Tunjangan, Potongan dan Perincian Gaji. Sedangkan pada Gambar 9 adalah tampilan dari menu utama User (Kepala KSP) yang hanya bisa melihat Laporan Data Pegawai, Tunjangan, Potongan dan Perincian Gaji saja.

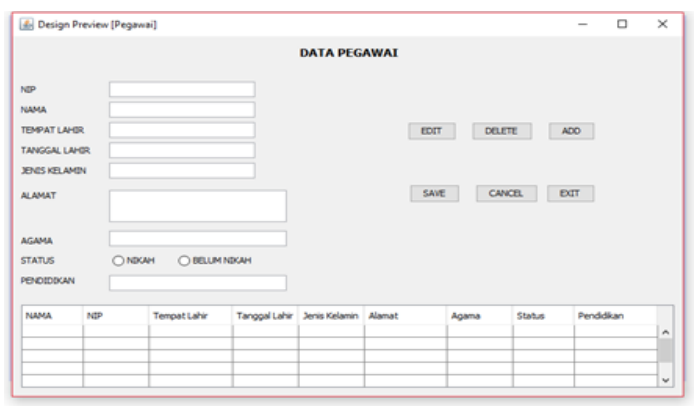

Gambar 10. Data Pegawai

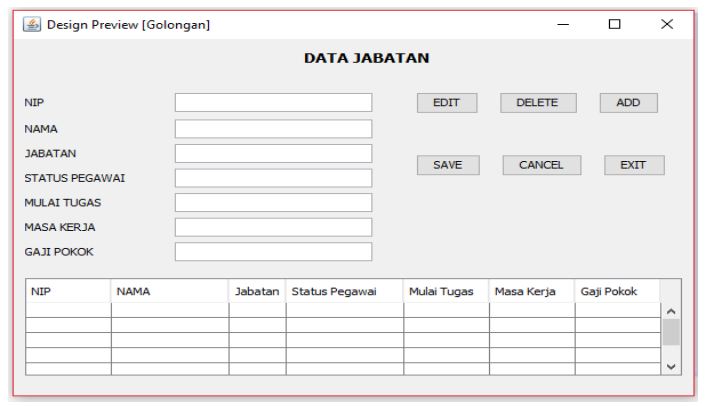

Gambar 11. Data Jabatan

Gambar 10 merupakan form dari pegawai yang fungsinya untuk proses peng-inputan, penghapusan, dan mengubah data dari pegawai. Isi dalam Form Pegawai adalah:NAMA, 
TEMPAT LAHIR, TANGGAL LAHIR, JENIS KELAMIN, ALAMAT, AGAMA, STATUS dan PENDIDIKAN.

Gambar 11 merupakan form dari jabatan yang fungsinya untuk proses peng-inputan, penghapusan, dan mengubah data dari jabatan. Isi dalam Form jabatan adalah:NIP, NAMA, JABATAN, STATUS PEGAWAI, MULAI TUGAS, MASA KERJA dan GAJI POKOK.

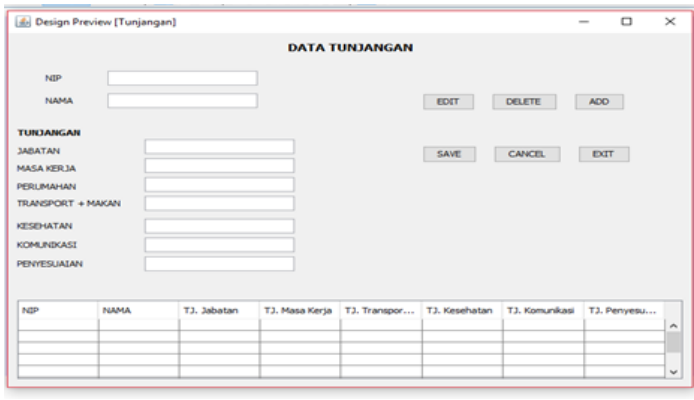

Gambar 12. Data Tunjangan

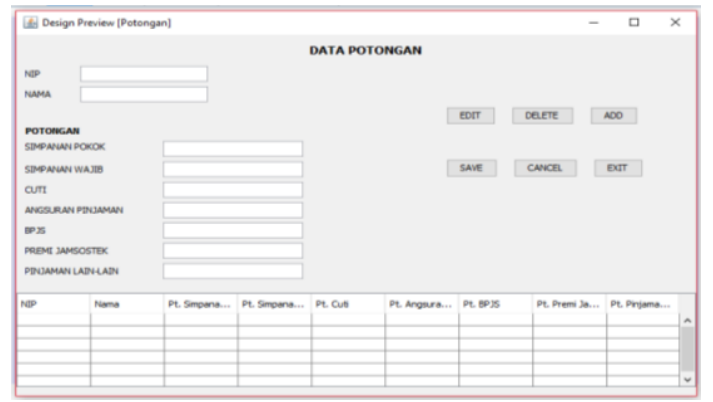

Gambar 13. Data Potongan

Gambar 12 merupakan form dari tunjangan yang fungsinya untuk proses peng-inputan, penghapusan, dan mengubah data dari tunjangan. Isi dalam Form tunjangan adalah:NIP, NAMA, JABATAN, MASA KERJA, PERUMAHAN, TRANSPORT+MAKAN, KESEHATAN, KOMUNIKASI dan PENYESUAIAN.

Gambar 13 merupakan form dari potongan yang fungsinya untuk proses peng-inputan, penghapusan, dan mengubah data dari potongan. Isi dalam Form potongan adalah:NIP, NAMA, SIMPANAN POKOK, SIMPANAN WAJIB, CUTI, ANGSURAN PINJAMAN, BPJS, PREMI JAMSOSTEK dan PINJAMAN LAIN-LAIN.

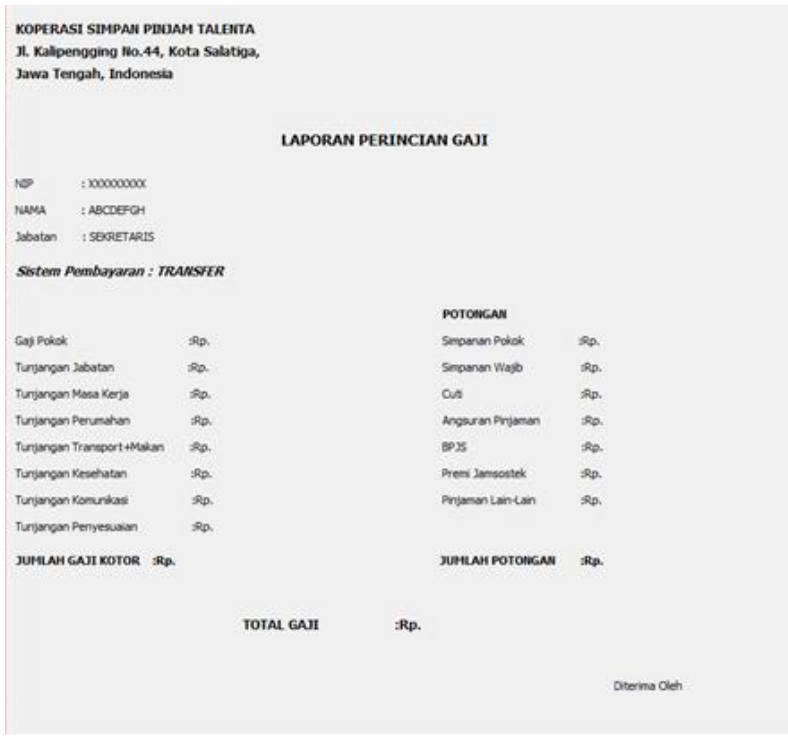

Gambar 14. Laporan Perincian Gaji

Gambar 14 merupakan form dari Laporan Perincian Gaji, didalam form ini terdapat perincian lengkap gaji dari masing-masing pegawai KSP Talenta. Didalam laporan tersebut berisikan NIP, NAMA, Jabatan dari pegawai. Sitem pembayaran gaji yaitu menggunakan proses Transfer. Gaji Pokok, Tunjangan Jabatan, Tunjangan Masa Kerja, Tunjangan Perumahan, Tunjangan Transport+Makan, Tunjangan Kesehatan, Tunjangan Komunikasi dan Tunjangan penyesuaian akan ditambahkan yang hasilnya akan ditampilkan di Jumlah Gaji Kotor. Simpanan Pokok, Simpanan Wajib, Cuti, Angsuran Pinjaman, BPJS, Premi Jamsostek dan Pinjaman Lain-lain akan ditambahkan yang hasilnya akan ditampilkan pada Jumlah 
Potongan. Kemudian yang terakhir Total Gaji adalah hasil dari pengurangan Jumlah Gaji kotor yang dikurangi Jumlah Potongan yang hasilnya akan ditempatkan di Total Gaji.

\subsection{Pengujian Sistem}

Aplikasi Sistem Informasi penggajian pada KSP Talenta ini diuji untuk mengetahui kinerjanya. Pengujian dilakukan menggunakan Blackbox dengan cara menjalankan fungsi pada sistem yang berjalan dimulai dari login, logout, input data karyawan dan klik laporan. Setelah melakukan penggajian tersebut dihasilkan tabel sebagai berikut.

Tabel 1 Hasil Pengujian Blackbox

\begin{tabular}{|c|c|c|c|c|c|}
\hline No & $\begin{array}{c}\text { Point } \\
\text { Pengujian }\end{array}$ & $\begin{array}{l}\text { Validasi } \\
\text { Input }\end{array}$ & Pengamatan & $\begin{array}{c}\text { Hasil } \\
\text { Uji }\end{array}$ & $\begin{array}{c}\text { Status } \\
\text { Uji }\end{array}$ \\
\hline \multirow[t]{3}{*}{1} & Login & $\begin{array}{l}\text { Verifikasi } \\
\text { Usemame } \\
\text { dan } \\
\text { password }\end{array}$ & $\begin{array}{c}\text { Usemame } \\
\text { dan } \\
\text { Password } \\
\text { benar }\end{array}$ & Valid & OK \\
\hline & & & $\begin{array}{c}\text { Usemame } \\
\text { salah dan } \\
\text { Password } \\
\text { benar }\end{array}$ & Invalid & OK \\
\hline & & & $\begin{array}{c}\text { Usemame } \\
\text { benar dan } \\
\text { Password } \\
\text { salah }\end{array}$ & Invalid & OK \\
\hline 2 & Logout & $\begin{array}{l}\text { Keluar } \\
\text { aplikasi }\end{array}$ & $\begin{array}{l}\text { Klik tombol } \\
\text { logout }\end{array}$ & Valid & OK \\
\hline 3 & $\begin{array}{c}\text { Input Data } \\
\text { Pegawai }\end{array}$ & $\begin{array}{c}\text { Dapat } \\
\text { memasukan } \\
\text { data } \\
\text { pegawai }\end{array}$ & $\begin{array}{c}\text { pengisian } \\
\text { data sesuai } \\
\text { yang } \\
\text { diharapkan }\end{array}$ & Valid & OK \\
\hline 4 & $\begin{array}{c}\text { Input Data } \\
\text { Jabatan }\end{array}$ & $\begin{array}{l}\text { Dapat } \\
\text { memasukan } \\
\text { data } \\
\text { jabatan }\end{array}$ & $\begin{array}{c}\text { pengisian } \\
\text { data sesuai } \\
\text { yang } \\
\text { diharapkan }\end{array}$ & Valid & OK \\
\hline 5 & $\begin{array}{l}\text { Input Data } \\
\text { Tunjangan }\end{array}$ & $\begin{array}{l}\text { Dapat } \\
\text { memasukan } \\
\text { data } \\
\text { tunjangan }\end{array}$ & $\begin{array}{c}\text { pengisian } \\
\text { data sesuai } \\
\text { yang } \\
\text { diharapkan }\end{array}$ & Valid & OK \\
\hline 6 & $\begin{array}{c}\text { Input Data } \\
\text { Potongan }\end{array}$ & $\begin{array}{c}\text { Dapat } \\
\text { memasukan } \\
\text { data } \\
\text { potongan }\end{array}$ & $\begin{array}{c}\text { pengisian } \\
\text { data sesuai } \\
\text { yang } \\
\text { diharapkan }\end{array}$ & Valid & OK \\
\hline 7 & $\begin{array}{c}\text { Klik } \\
\text { Laporan }\end{array}$ & Data masuk & $\begin{array}{c}\text { Data sesuai } \\
\text { yang } \\
\text { diharapkan }\end{array}$ & Valid & OK \\
\hline
\end{tabular}

Berdasarkan hasil uji blackbox pada Tabel 1 dapat dijelaskan proses yang terjadi pada sistem informasi penggajian KSP Talenta yang mencakup login, logout, input data karyawan dan klik laporan, data yang diinputkan terdapat dua bagian yaitu valid dan invalid. Data tersebut diuji coba sesuai pada Tabel 1 dimana data input dan output akan sesuai yang diharapkan.

\section{Kesimpulan dan Saran}

Berdasarkan pembahasan tentang perancangan sistem informasi penggajian karyawan KSP Talenta, dapat diambil kesimpulan yaitu: Sistem Informasi Penggajian pada KSP Talenta ini sangat membantu Admin/Bendahara dalam melakukan proses penggajian karyawan dan proses pembuatan laporan. Sistem Informasi Penggajian pada KSP Talenta dibuat didalam sistem informasi berbasis desktop, sistem tersebut akan mencatat data secara cepat dan akurat. Saran penelitian selanjutnya adalah sistem informasi pengajian karyawan pada KSP Talenta dapat dikembangkan lagi supaya tidak hanya sebuah sistem informasi melainkan sistem informasi perusahaan secara meluas seperti sistem informasi keuangan dan dalam 
penerapannya sistem informasi penggajian hendaknya dapat dikembangkan lagi menjadi berbasis web dan sistem mungkin dapat dilengkapi dengan keamanan seperti antivirus.

\section{References}

[1] Amstrong, Michael dan Helen Murlis. 1995. 'Sistem Penggajian. Jakarta : PT. Pustaka Binaman Pressindo'.

[2] Umbu. D. Tanda, Andi M. 2012. 'Sistem Informasi Penggajian dan Kepegawaian Berbasis Dekstop (Studi Kasus: Sekolah Menengah Atas (SMA) Negeri 2 Waingapu)'.

[3] Wardany, Aprilia Kusuma 2015. 'Sistem Informasi Penggajian Karyawan Shift Khusus Pagi PT. Tiga Manunggal Synthetic Industries'.

[4 Suyanti. 2017. 'Perancangan Sistem Informasi Penggajian Karyawan berbasis Dekstop Pada PT. BS Logistics Batam'.

[5] Agustina, Rina, dan Sukadi. 2014. 'Sistem Informasi Penggajian Guru (Pada Sekolah Menengah Kejuruan PGRI 1 Pacitan)'. Sentra Penelitian Engineering dan Edukasi Volume 6 No 3.

[6] Setyawan, Arif, dan Joko Wandyatmono. 2009. 'Sistem Informasi Penggajian Pegawai Kecamatan Geneng Kabupaten Ngawi'. Sentra Penelitian Engineering dan Edukasi Volume 1 No 3.

[7] Nggebu, Luisa Cornalia. 2013. 'Perancangan dan Implementasi Sistem Informasi Manajemen Penggajian Berbasis Web Studi Kasus: Badan Penanaman Modal Daerah Kota Kupang'.

[8] Reni Afiandari. 2016. 'Perancangan Sistem Informasi Penggajian Karyawan Studi Kasus PT. Bayuadji Nusantara Industries (PT. BNI) Kabupaten Semarang'.

[9] Jayanti, Dwi, dan Siska Iriani. 2014. 'Sistem Informasi Penggajian Pada CV. Blumbang Sejati Pacitan'. Sentra Penelitian Engineering dan Edukasi - Volume 6 No 3.

[10] Zulnalis. 2016. 'Sistem Informasi Penggajian Karyawan (Studi Kasus : PT. Arus Global Security Service Jakarta)'. Jakarta: STMIK Antar Bangsa.

[11] Burhan, Muhammad Azmi. 2013. 'Sistem Informasi Penggajian Berbasis Dekstop Pada PT. Usaha Tangguh Mandiri'.

[12] Firdaus, Muhammad. 2017. 'Rancang Bangun Sistem Informasi Penggajian Karyawan Di CV.Sogan Jaya Abadi Dengan Metode Prototyping'. 